\title{
Parental, Perinatal, and Childhood Risk Factors for Development of Irritable Bowel Syndrome: A Systematic Review
}

\begin{abstract}
En X S Low, ${ }^{1}$ Maimouna N K Al Mandhari, ${ }^{2}$ Charles C Herndon, ${ }^{3}$ Evelyn X L Loo, ${ }^{4,5}$ Elizabeth H Tham, ${ }^{5,7}$ and Kewin T H Siah ${ }^{2,6 *}$
${ }^{I}$ Department of Medicine, Ng Teng Fong General Hospital, National University Health System, Singapore, Singapore; ${ }^{2}$ Division of Gastroenterology and Hepatology, Department of Medicine, National University Hospital, Singapore, Singapore; ${ }^{3} G$ Oppenheimer Center for Neurobiology of Stress and Resilience (CNSR), David Geffen School of Medicine at UCLA, Los Angeles, CA, USA; ${ }^{4}$ Singapore Institute for Clinical Sciences (SICS), Agency for Science, Technology and Research (A*STAR), Singapore, Singapore; Departments of ${ }^{5}$ Pediatrics and ${ }^{6} M e d i c i n e$, Yong Loo Lin School of Medicine, National University of Singapore, Singapore, Singapore; and 'Khoo Teck Puat-National University Children's Medical Institute, National University Health System (NUHS), Singapore, Singapore
\end{abstract}

\section{Background/Aims}

Adverse early life experiences are associated with the development of stroke, cancer, diabetes, and chronic respiratory and ischemic heart diseases. These negative experiences may also play a role in the development of irritable bowel syndrome (IBS) - a functional gastrointestinal disease. This review discusses the research to date on the parental, perinatal, and childhood risk and protective factors associated with the development of IBS.

\section{Methods}

A literature search was completed for studies published between 1966 and 2018 that investigated premorbid factors occurring during the perinatal and childhood periods as well as parental factors that were associated with the development of IBS.

\section{Results}

Twenty-seven studies fulfilled the review criteria. Risk factors that appeared in more than one study included: (1) parental IBS, substance abuse, parental punishment, and rejection as parental risk factors; (2) low birth weight as a perinatal risk factor; and (3) crowded living conditions in low-income families, childhood anxiety, depression, or child abuse as childhood risk factors. Protective factors for IBS were emotional warmth from the parents and being born to an older mother.

\section{Conclusions}

More effort is needed to identify what fetal and maternal factors are associated with low birth weight and IBS. A well-executed prospective birth cohort with a collection of bio-samples and functional data will provide a better understanding of how adversity and the interplay between genetics, epigenetics, and numerous risk factors affect the development of IBS.

(J Neurogastroenterol Motil 2020;26:437-446)

\section{Key Words}

Infant; Irritable bowel syndrome; Maternal-child nursing; Mother-child relations; Perinatal care

Received: May 12, 2020 Revised: September 13, 2020 Accepted: September 20, 2020

(.) This is an Open Access article distributed under the terms of the Creative Commons Attribution Non-Commercial License (http://creativecommons. org/licenses/by-nc/4.0) which permits unrestricted non-commercial use, distribution, and reproduction in any medium, provided the original work is properly cited.

*Correspondence: Kewin T H Siah, MD Division of Gastroenterology and Hepatology, University Medicine Cluster, National University Health System, Level 10 Tower Block, 1 E Kent Ridge Road, Singapore 119228, Singapore Tel: +82-65-67795555, Fax: +65-67751518,E-mail: kewin_siah@nuhs.edu.sg En X S Low and Maimouna N K Al Mandhari equally contributed to this study. 


\section{Introduction}

Irritable bowel syndrome (IBS) is one of the most common functional gastrointestinal disorders (FGIDs) which is characterized by recurrent abdominal pain associated with an abnormal bowel habit. Patients with IBS often complain of abdominal discomfort or bloating and irregular bowel habits like diarrhea, constipation or mixed bowel habits.

The Rome Foundation performed the first global study of the epidemiology and impact of the FGIDs in 33 countries. The survey was completed by 73076 respondents. The overall IBS prevalence was $3.8 \%$ by Rome IV criteria and $10.1 \%$ by Rome III criteria (by internet survey), and the pooled IBS prevalence rates were $1.5 \%$ using Rome IV and 3.5\% using Rome III (by household survey). ${ }^{2}$ For a long time, children with symptoms of IBS were more likely to be diagnosed as having recurrent abdominal pain. This changed in 1995 when an international group of pediatric gastroenterologists defined the diagnostic criteria for FGIDs in childhood. These criteria were published 4 years later as part of the Rome II criteria and have since been updated in Rome IV. The prevalence of IBS in American children ranges from $1.2 \%$ to $2.9 \%{ }^{3}$ IBS also bears a significant burden on society and individuals. In the United States, IBS accounts for an estimated $\$ 1.7$ billion and $\$ 20.0$ billion in di- rect and indirect medical costs annually. ${ }^{4}$ IBS patients have reflected a significantly impaired quality of life comparable to that of patients with other chronic diseases such as ischemic heart disease and diabetes mellitus. ${ }^{5}$

Multiple factors are thought to play a role in the pathophysiology of IBS. These factors include visceral hypersensitivity, dysbiosis of the gut microbiota, immune activation, and alterations in brain function. IBS may be triggered by stress, mood disorders, gastrointestinal infection, and adverse early life experiences. ${ }^{6,7}$ This systematic review aims to summarize the current understanding of early life experiences (including parental, perinatal, and childhood risk factors) that may contribute to the development of IBS. We also discuss the possible links between these risk factors with potential pathophysiological mechanisms.

\section{Methodology}

We performed a computer-assisted literature search of Cochrane databases, PubMed, Web of Science, and Embase from year 1966 to 2018. Please refer to the Supplementary Figure for the PRISMA flow diagram for this systematic review. Using medical subject heading (MeSH) and title words for the ("Colonic Diseases, Functional" [Mesh] or "Irritable Bowel Syndrome" [Mesh]) AND ("risk factors" OR "risk") AND ("Prenatal Care" [Mesh]

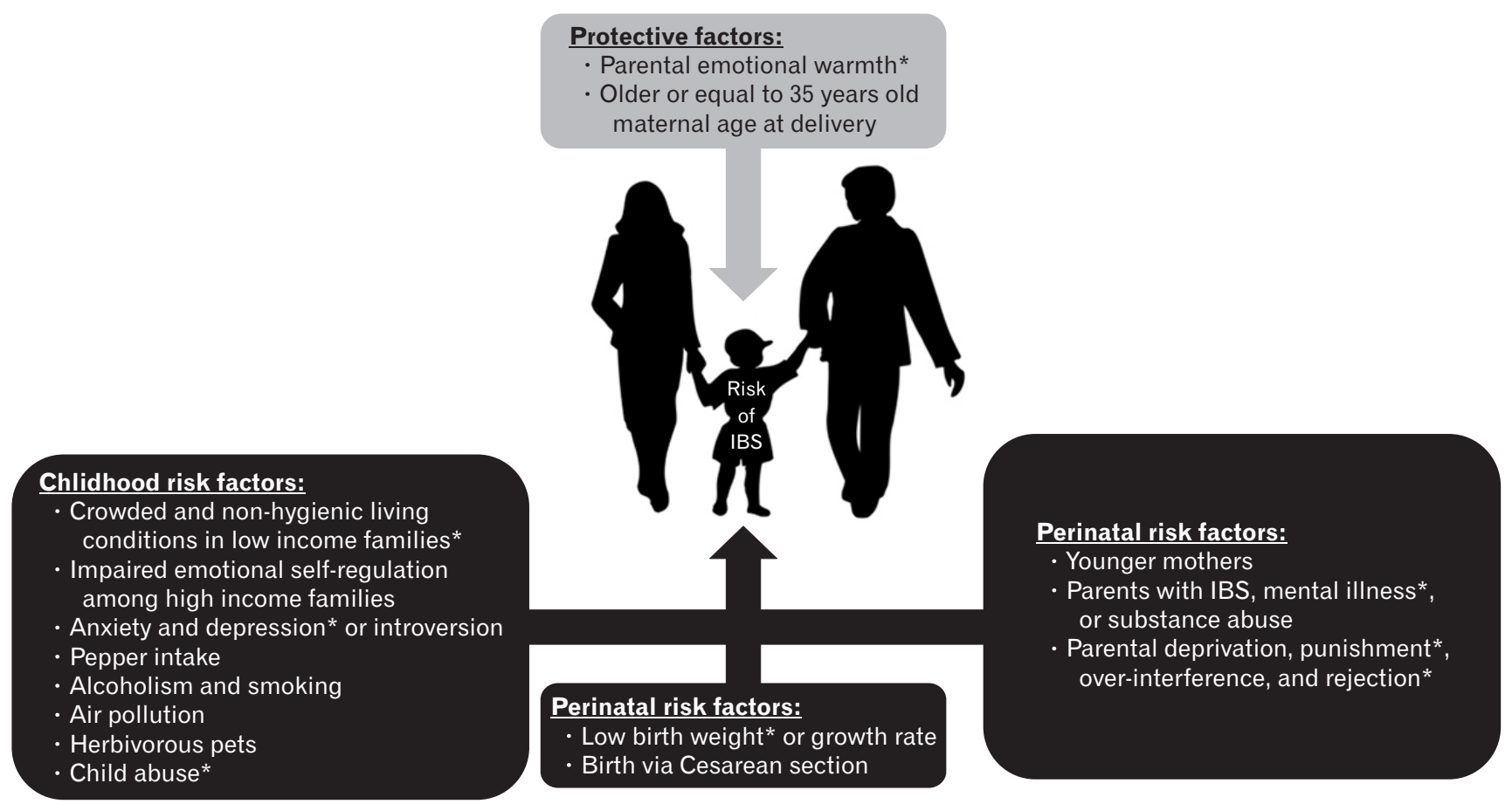

Figure 1. Summary of early life protective and risk factors for irritable bowel syndrome (IBS). *Demonstrated in $>1$ study. 
OR "Perinatal Care" [Mesh] OR "Infant" [Mesh] OR "Child Care" [Mesh] OR "Child" [Mesh] OR "Maternal Exposure" [Mesh] OR "Maternal-Child Nursing”[Mesh] OR "Maternal-Fetal Exchange" [Mesh] OR "Mother-Child Relations"[Mesh] OR “Maternal-Fetal Relations" [Mesh] OR "Mothers"[Mesh] OR "Maternal Behavior" [Mesh] OR "Maternal Health" [Mesh]) revealed 554 results. We also searched for reference lists of relevant articles to identify additional relevant citations and found another 88 studies. We included studies that (1) were conducted in adolescents or adults with IBS, (2) investigated premorbid and comorbidity factors occurring specifically during the early childhood and perinatal periods as well as parental risk factors that were associated with the development of IBS.

Reference lists of relevant articles were reviewed for additional citations. Articles had to be in English, and full manuscripts had to be retrievable. The titles and abstracts of all citations identified by the literature search were reviewed. Potentially relevant studies were retrieved, reviewed in full, and the selection criteria were applied. All studies conducted in both clinical settings and population-based samples were considered. Two investigators independently screened for eligible studies based on the selection criteria, and any discrepancies were resolved by consensus.

\section{Results}

Twenty-seven articles met the inclusion criteria. We separated the studies into 3 early life factors: perinatal, parental, and childhood factors (Fig. 1).

\section{Perinatal Factors}

Potential perinatal risk factors include a shorter period of breastfeeding, low birth weight, ${ }^{8-10}$ Caesarean birth, ${ }^{10}$ and gastric suction at birth ${ }^{11}$ (Table 1). It is not understood whether delayed utero growth directly results in low birth weight and in turn leads to IBS, or if low birth weight is a prospective indicator for subsequent early life problems that can lead to IBS. Figure 2 shows the forest plot of association between low birth weight and development of IBS. It has been hypothesized that visceral irritation by gastric suction at birth promotes long-term visceral hypersensitivity and cognitive hypervigilance, leading to an increased prevalence of functional

\section{Low birth weight and development of IBS}

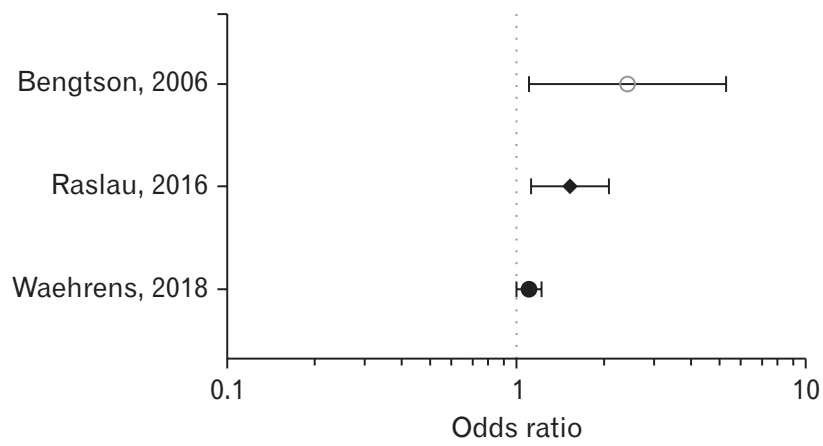

Figure 2. Forest plot shows the association between low birth weight and development of irritable bowel syndrome. Bengtson et $\mathrm{al}^{8}$ (2006) found low birth weight below $1500 \mathrm{~g}$ to be significantly associated with higher irritable bowel syndrome (IBS) risk after adjustment for gestational age and history of same health issues in both twins. Raslau et $\mathrm{al}^{9}$ (2016) found lower birth weight to be associated with increased odds of IBS. Waehrens et $\mathrm{al}^{10}$ (2018) found birth weight below 2500 $\mathrm{g}$ to be associated with increased risk of IBS after adjusting for sex, birth year, gestational age, fetal growth, birth order, delivery mode, multiple birth status, maternal age at delivery, maternal marital status, paternal length of education, maternal length of education as well as parental history of anxiety, depression, and IBS.

Table 1. Perinatal Factors and Development of Irritable Bowel Syndrome

\begin{tabular}{|c|c|c|c|c|c|}
\hline Study & Population & IBS diagnosis & Methodology & Sample size & Risk factors \\
\hline $\begin{array}{l}\text { Anand et al, }{ }^{11} 2004, \\
\text { Sweden }\end{array}$ & Birth records & IBS symptoms & Matched case-control & 96 & Gastric suction at birth \\
\hline $\begin{array}{l}\text { Bengtson et al, }{ }^{8} 2006 \text {, } \\
\text { Norway }\end{array}$ & Norway Birth Registry & $\begin{array}{l}\text { Self-completed } \\
\text { Questionnaire }\end{array}$ & Retrospective & 345 & $\begin{array}{l}\text { Low birth weight } \\
(<1500 \mathrm{~g})\end{array}$ \\
\hline $\begin{array}{l}\text { Raslau et al, }{ }^{9} 2016, \\
\text { USA }\end{array}$ & Survey responders & $\begin{array}{l}\text { Survey, self-report } \\
\text { Talley, Rome }\end{array}$ & $\begin{array}{l}\text { A population-based nested } \\
\text { case-control study }\end{array}$ & 89 & Low birth weight \\
\hline $\begin{array}{l}\text { Koloski et al, }{ }^{12} 2015 \text {, } \\
\text { Australia }\end{array}$ & Survey responders & $\begin{array}{l}\text { Self-completed } \\
\text { Questionnaire } \\
\text { Rome I }\end{array}$ & $\begin{array}{l}\text { Prospective data collection } \\
\text { Recollection }\end{array}$ & 130 & $\begin{array}{l}\text { Shorter duration of } \\
\text { breastfeeding }\end{array}$ \\
\hline $\begin{array}{l}\text { Waehrens et al, }{ }^{10} 2018 \text {, } \\
\text { Sweden }\end{array}$ & Swedish Birth Registry & $\begin{array}{l}\text { ICD Codes - } \\
\text { Record Review }\end{array}$ & Longitudinal Birth Cohort & 24633 & Caesarean, low birth weight \\
\hline
\end{tabular}

IBS, irritable bowel syndrome; ICD, International Classification of Diseases. 
intestinal disorders later in life (odds ratio 2.99). ${ }^{11}$ Koloski et al ${ }^{12}$ reported that a shorter period of breastfeeding was significantly associated with IBS (5.6 months vs 8.1 months, $P=0.009$ ). This may be due to the colonization by beneficial bacteria in breast milk that stifles the growth of pathogens like Clostridium difficile.

\section{Parental Factors}

Parental support and maternal maturity had been shown to influence the development of IBS. These factors were recently explored by Waehrens et $\mathrm{al}^{10}$ in a study of 25000 patient records from Sweden's national birth registry. ${ }^{10}$ They found that the children of mothers who were young, divorced or widowed, and with an education of 10-14 years were at higher risk for developing IBS. These factors may reflect the importance of parenting skills, and available socioeconomic and support network provided by a traditional nucleus family. Parental reinforcement, modeling of symptoms, coping strategies, and psychological distress during childhood have been shown to influence the development of IBS (Table 2). Interestingly, a parental history of IBS was associated with depression and anxiety, suggesting a shared, familial risk factor. ${ }^{10} \mathrm{~A}$ similar finding was made by van Tilburg et $\mathrm{al}^{16}$ who found a marked tendency for IBS to cluster within families, especially those with mothers suffering from anxiety, depression, and stress. A twin study found that social learning may contribute to IBS to an equal or higher degree than genetic factors. ${ }^{13}$ Parenting behaviors may also have a significant impact on IBS; parental punishment, over interference, rejection, and over-protection can put children at risk for IBS. ${ }^{19,20}$ Receiving emotional warmth from the parents may protect children from IBS. $^{14,15}$

\section{Childhood Factors}

Studies on early life risk factors for the development of IBS have focused on the role of socioeconomic factors, environmental factors, and antecedent diseases (Table 3). There had been contradicting findings of the risk of socioeconomic status. An Africabased study among school children found an association between a lower socioeconomic status and a history of gastroenteritis. ${ }^{19}$ Several studies have looked at adult IBS patients' childhood recollections to evaluate early risk factors for IBS. Mendall and $\mathrm{Kumar}^{20}$ investigated 421 adult subjects attending a general practice health screening clinic in the United Kingdom and found that adults were at greater risk of developing IBS if they had grown up with a father working in manual labor or in a home with a living density of more than one person per room.

Table 2. Parental Factors and Development of Irritable Bowel Syndrome

\begin{tabular}{|c|c|c|c|c|c|c|}
\hline Study & Population & IBS diagnosis & Methodology & $\begin{array}{l}\text { Sample } \\
\text { size }\end{array}$ & Risk factors & $\begin{array}{l}\text { Protective } \\
\text { factors }\end{array}$ \\
\hline $\begin{array}{l}\text { Hislop, }^{17} \\
\text { 1979, Australia }\end{array}$ & Medical records & $\begin{array}{l}\text { Physician-diagnosed } \\
\text { IBS }\end{array}$ & Recollection & 333 & $\begin{array}{l}\text { Childhood parental deprivation } \\
\text { (parental loss, alcoholic, } \\
\text { unsatisfactory relationships) }\end{array}$ & \\
\hline $\begin{array}{l}\text { Levy et al, }{ }^{13} \\
\text { 2001, USA }\end{array}$ & $\begin{array}{l}\text { Population - } \\
\text { Twins }\end{array}$ & Self Questionnaire & $\begin{array}{l}\text { Prospective data } \\
\text { collection }\end{array}$ & 6060 & Mother/father with IBS & \\
\hline $\begin{array}{l}\text { Lackner et al, } \\
\text { 2004, USA }\end{array}$ & Clinic referrals & $\begin{array}{l}\text { Self Questionnaire } \\
\text { Rome II + Physician }\end{array}$ & $\begin{array}{l}\text { Prospective data } \\
\text { collection }\end{array}$ & 81 & $\begin{array}{l}\text { Paternal parenting behaviors } \\
\text { (rejection or hostility) }\end{array}$ & \\
\hline $\begin{array}{l}\text { Xing et al, } \\
\text { 2014, China }\end{array}$ & School students & $\begin{array}{l}\text { Self Questionnaire } \\
\text { Rome III }\end{array}$ & $\begin{array}{l}\text { Prospective data } \\
\text { collection }\end{array}$ & 96 & $\begin{array}{l}\text { Parental punishment, Paternal } \\
\text { rejection, Maternal over- } \\
\text { interference, Paternal overprotection }\end{array}$ & $\begin{array}{l}\text { Parental } \\
\text { emotional } \\
\text { warmth }\end{array}$ \\
\hline $\begin{array}{l}\text { Knight et al, } \\
2015, \text { USA }\end{array}$ & Medical records & $\begin{array}{l}\text { Self Questionnaire } \\
\text { Talley }\end{array}$ & $\begin{array}{l}\text { Nested } \\
\text { Case-control }\end{array}$ & 287 & $\begin{array}{l}\text { Family history of mental illness/ } \\
\text { alcohol, substance abuse problems }\end{array}$ & \\
\hline $\begin{array}{l}\text { van Tilburg et al, } \\
\text { 2015, USA }\end{array}$ & Clinic visits & $\begin{array}{l}\text { Self Questionnaire } \\
\text { Rome I }\end{array}$ & Retrospective & 296 & $\begin{array}{l}\text { Mothers with psychological traits } \\
\text { (anxiety, depression, and } \\
\text { somatization), Family stress }\end{array}$ & \\
\hline $\begin{array}{l}\text { Waehrens et al, } \\
\text { 2018, Sweden }\end{array}$ & $\begin{array}{l}\text { Swedish Birth } \\
\text { Registry }\end{array}$ & $\begin{array}{l}\text { ICD Codes - Record } \\
\text { Review }\end{array}$ & $\begin{array}{l}\text { Longitudinal } \\
\text { Birth Cohort }\end{array}$ & 24633 & $\begin{array}{l}\text { Young maternal age }<20 \text { years old, } \\
\text { Maternal marital status (divorced/ } \\
\text { widowed), Maternal education of } \\
\text { 10-14 years old, Parental history } \\
\text { of IBS, anxiety, depression }\end{array}$ & $\begin{array}{c}\geq 35 \text { years old } \\
\text { maternal } \\
\text { delivery }\end{array}$ \\
\hline
\end{tabular}

IBS, irritable bowel syndrome; ICD, International Classification of Diseases. 
Table 3. Childhood Factors and Development of Irritable Bowel Syndrome

\begin{tabular}{|c|c|c|c|c|c|}
\hline Study & Population & IBS diagnosis & Methodology & $\begin{array}{l}\text { Sample } \\
\text { size }\end{array}$ & Risk factors \\
\hline $\begin{array}{l}\text { Walker et al, } \\
\text { 1993, USA }\end{array}$ & GI clinic (adults) & $\begin{array}{l}\text { Physician-diagnosed } \\
\text { IBS }\end{array}$ & $\begin{array}{l}\text { Prospective data } \\
\text { Recollection }\end{array}$ & 28 & Severe Childhood sexual abuse \\
\hline $\begin{array}{l}\text { Talley et al, }{ }^{28} \\
1994, \text { USA }\end{array}$ & Survey (adults) & $\begin{array}{l}\text { Self Questionnaire } \\
\text { BDQ }\end{array}$ & $\begin{array}{l}\text { Prospective data } \\
\text { Recollection }\end{array}$ & 130 & Childhood abuse \\
\hline $\begin{array}{l}\text { Mendall and Kumar, } \\
\text { 1998, UK }\end{array}$ & GP clinic (adults) & $\begin{array}{l}\text { Self Questionnaire } \\
\text { Manning }\end{array}$ & $\begin{array}{l}\text { Prospective data } \\
\text { Recollection }\end{array}$ & 48 & $\begin{array}{l}\text { Antibiotic use Privileged childhood } \\
\text { living conditions }\end{array}$ \\
\hline $\begin{array}{l}\text { Talley et al, } \\
1998 \text { Australia }\end{array}$ & Voters (adults) & $\begin{array}{l}\text { Self Questionnaire } \\
\text { BSQ }\end{array}$ & $\begin{array}{l}\text { Prospective data } \\
\text { Recollection }\end{array}$ & 90 & Childhood abuse \\
\hline $\begin{array}{l}\text { Salmon et } \mathrm{al}^{22} \\
\text { 2003, UK }\end{array}$ & Clinic visits (adults) & $\begin{array}{l}\text { Self Questionnaire + } \\
\text { Physician }\end{array}$ & $\begin{array}{l}\text { Prospective data } \\
\text { Recollection }\end{array}$ & 64 & $\begin{array}{l}\text { Childhood sexual, physical and } \\
\text { psychological abuse }\end{array}$ \\
\hline $\begin{array}{l}\text { Howell et al, } \\
2004 \text { Australia }\end{array}$ & Birth Registry & $\begin{array}{l}\text { Self Questionnaire } \\
\text { BSQ }\end{array}$ & $\begin{array}{l}\text { Longitudinal } \\
\text { Birth Cohort }\end{array}$ & 157 & Affluent childhood environment \\
\hline $\begin{array}{l}\text { Dong et al, } \\
2005 \text {, China }\end{array}$ & Students & $\begin{array}{l}\text { Self Questionnaire } \\
\text { Rome II }\end{array}$ & $\begin{array}{l}\text { Prospective data } \\
\text { collection }\end{array}$ & 716 & $\begin{array}{l}\text { Anxiety, depression, introverted, } \\
\text { food habits (excessive pepper), } \\
\text { personal habits (smoking/alcoholism), } \\
\text { bad exterior environment } \\
\text { (abdominal operation, abuse of } \\
\text { antibiotics, exposure to coldness, } \\
\text { and fatigue), single parent }\end{array}$ \\
\hline $\begin{array}{l}\text { Son et al, } \\
\text { 2009, S Korea }\end{array}$ & Females students & $\begin{array}{l}\text { Self Questionnaire } \\
\text { Rome II }\end{array}$ & $\begin{array}{l}\text { Prospective data } \\
\text { collection }\end{array}$ & 104 & $\begin{array}{l}\text { Higher stress, anxiety, and } \\
\text { depression }\end{array}$ \\
\hline $\begin{array}{l}\text { Beesley et al, } \\
\text { 2010, UK }\end{array}$ & Clinic visits (adults) & Physician Rome III & $\begin{array}{l}\text { Prospective data } \\
\text { Recollection }\end{array}$ & 75 & $\begin{array}{l}\text { Childhood sexual abuse A tendency } \\
\text { to suppress anger, anxious }\end{array}$ \\
\hline $\begin{array}{c}\text { Tietjen et al, }^{24} \\
2010, \text { USA }\end{array}$ & Clinic visits (adults) & $\begin{array}{l}\text { Self-report }+ \\
\text { Physician }\end{array}$ & $\begin{array}{l}\text { Prospective data } \\
\text { Recollection }\end{array}$ & 418 & emotional abuse \\
\hline $\begin{array}{l}\text { Zhou et al, } \\
\text { 2012, China }\end{array}$ & Students & $\begin{array}{l}\text { Interview } \\
\text { Questionnaire less }\end{array}$ & $\begin{array}{l}\text { Prospective data } \\
\text { collection }\end{array}$ & 268 & Poor sleep \\
\hline $\begin{array}{l}\text { Koloski et al, } \\
\text { 2015, Australia }\end{array}$ & $\begin{array}{l}\text { Survey responders } \\
\text { (adults) }\end{array}$ & $\begin{array}{l}\text { Self Questionnaire } \\
\text { Rome I }\end{array}$ & $\begin{array}{l}\text { Prospective data } \\
\text { Recollection }\end{array}$ & 130 & $\begin{array}{l}\text { Sharing bedroom to } 5 \text { years old } \\
\text { Exposure to herbivore pet (horse/ } \\
\text { bird) to } 5 \text { years old }\end{array}$ \\
\hline $\begin{array}{l}\text { Adeniyi et al, }{ }^{19} \\
2017 \text { Nigeria }\end{array}$ & Students & $\begin{array}{l}\text { Self Questionnaire, } \\
\text { Rome III }\end{array}$ & $\begin{array}{l}\text { Prospective data } \\
\text { collection }\end{array}$ & 62 & $\begin{array}{l}\text { Lower socioeconomic status } \\
\text { Past history of gastroenteritis }\end{array}$ \\
\hline $\begin{array}{l}\text { Tan et al, } \\
\text { 2017, Taiwan }\end{array}$ & $\begin{array}{l}\text { National Health } \\
\text { Insurance Research } \\
\text { Database }\end{array}$ & $\begin{array}{l}\text { Physician-diagnosed } \\
\text { IBS }\end{array}$ & Retrospective & 11242 & $\begin{array}{l}\text { Antecedent allergic diseases, allergic } \\
\text { rhinitis, higher clinical allergy } \\
\text { burden. }\end{array}$ \\
\hline $\begin{array}{l}\text { Rajindrajith et al, } \\
\text { 2018, Sri Lanka }\end{array}$ & Students & $\begin{array}{l}\text { Self Questionnaire, } \\
\text { Rome III }\end{array}$ & $\begin{array}{l}\text { Prospective data } \\
\text { collection }\end{array}$ & 1972 & $\begin{array}{l}\text { Exposure to physical, emotional } \\
\text { and sexual abuse }\end{array}$ \\
\hline $\begin{array}{l}\text { Tan et al, } \\
\text { 2019, Taiwan }\end{array}$ & $\begin{array}{l}\text { National Health } \\
\text { Insurance Research } \\
\text { Database }\end{array}$ & $\begin{array}{l}\text { Physician-diagnosed } \\
\text { IBS }\end{array}$ & Retrospective & 3537 & Air pollutants \\
\hline
\end{tabular}

IBS, irritable bowel syndrome; GI, gastrointestinal; GP, general practitioner; BDQ, Bowel Disease Questionnaire; BSQ, Bowel Screening Questionnaire.

Conversely, Howell et $\mathrm{al}^{21}$ showed that children raised in an affluent environment were at greater risk of developing IBS. The authors postulated that the emphasis on academic achievement and behavioral self-regulation within this echelon of society might impair children's coping mechanisms, causing them to internalize stress. Another well-studied childhood risk factor for IBS is child abuse. Children are at an increased risk of developing IBS if they had been abused sexually, ${ }^{22,23}$ emotionally, ${ }^{24}$ physically, or psycho- 
logically ${ }^{22}$ during childhood. Figure 3 shows the forest plot of association between childhood sexual abuse and development of IBS. A study on school children in China found that certain psychological factors (anxiety, depression, and introverted personality), food habits (excessive intake of pepper), personal habits (alcoholism and smoking), adverse environmental exposures (history of dysentery, abdominal operation, overuse of antibiotics, exposure to coldness, and fatigue), and family dynamics (poor care by only a single parent) put children at higher risk of developing IBS. ${ }^{25}$ Koloski et al ${ }^{12}$ performed a population survey in Sydney which showed that adults who grew up sharing a bedroom or raising an herbivorous petboth of which may allow increased exposure of the gut to various microbes-were at greater risk of developing IBS.

\section{Childhood sexual abuse and development of IBS}

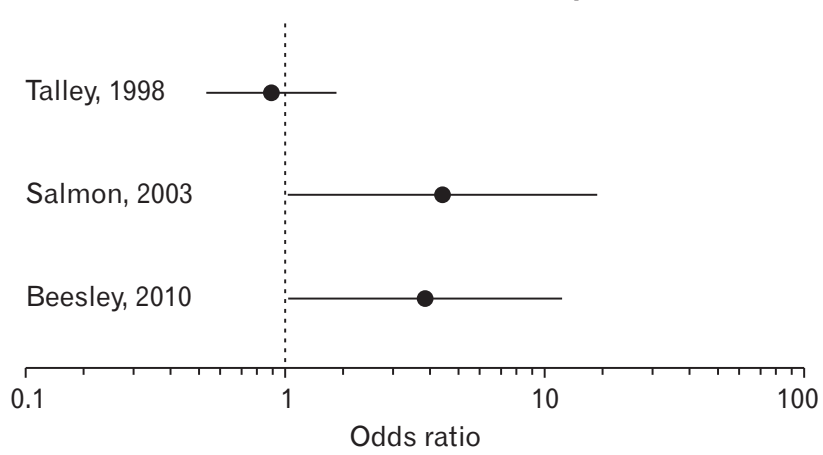

Figure 3. Forest plot shows the association between childhood sexual abuse and development of irritable bowel syndrome (IBS). Talley et $\mathrm{al}^{29}$ (1998) did not find childhood sexual abuse below 14 years to be associated with IBS after controlling for gender, age, psychological morbidity, and neuroticism. Salmon et $\mathrm{al}^{22}$ (2003) found childhood sexual abuse below 14 years to be a significant predictor of IBS as compared to physical disease. Beesley et $\mathrm{al}^{23}$ (2010) showed that IBS patients had a higher likelihood of remembering childhood sexual abuse occurring below 14 years as compared to Crohn's disease patients after controlling for gender.
In addition to these psychological, social, and environmental factors, allergic diseases have also been explored for their contribution to IBS. To date, there is conflicting evidence as to whether or not children with allergies are more susceptible to developing IBS. A study in Taiwan by Tan et al ${ }^{32}$ found that preschoolers with a history of allergic disease had an increased risk of subsequently developing IBS at school age.

Air pollution may put children at higher risk of IBS. The 2019 study by Tan et $\mathrm{al}^{26}$ showed that children exposed to higher concentrations of air pollution have an increased risk of IBS. The correlation persisted even after adjustment for monthly income, urban environments, number of consultations with or visits to a physician per year, and allergic diseases. This indicates that a crowded or stressful environment and the frequency of physician visits for other diseases were not confounding factors. Further studies are required to better elucidate the contribution of environmental and allergic factors in the pathogenesis of IBS.

\section{Post-infectious Irritable Bowel Syndrome}

Two population-based studies have been published on the relationship between childhood gastrointestinal infections and the development of IBS, also known as post-infectious IBS (PI-IBS; Table 4). Cremon et $\mathrm{al}^{34}$ studied 204 children exposed to salmonella contaminated tuna sauce and compared them with a healthy cohort. They found that childhood cases of gastroenteritis related to salmonella infection were at greater risk of subsequently developing IBS. Thabane et $\mathrm{al}^{35}$ studied a population exposed to a contaminated water supply and found that acute bacterial gastroenteritis was associated with subsequent cases of IBS in children and adults.

\section{Discussion}

Figure 1 summarizes the early life protective and risk factors for IBS, which we have discussed so far. Compared to other inflam-

Table 4. Risk Factors Associated With Post-Infectious Irritable Bowel Syndrome Patient

\begin{tabular}{|c|c|c|c|c|c|}
\hline Study & Population & IBS diagnosis & Methodology & Sample size & Risk factors \\
\hline $\begin{array}{l}\text { Thabane et al, } \\
\text { 2010, Canada }\end{array}$ & $\begin{array}{c}\text { Outbreak of GE } \\
\text { (water supply) }\end{array}$ & $\begin{array}{l}\text { Interview }+ \text { self } \\
\text { Questionnaire Talley }\end{array}$ & $\begin{array}{l}\text { Prospective } \\
\text { cohort }\end{array}$ & $\begin{array}{l}33 \text { IBS of } 467 \\
\text { exposed }\end{array}$ & $\begin{array}{l}\text { Acute bacterial gastroenteritis (Escherichia } \\
\text { coli, Campylobacter), diarrheal illness } \\
\text { lasting more than } 7 \text { days, weight loss }>10 \\
\text { pounds, and antibiotic use during the } \\
\text { outbreak }\end{array}$ \\
\hline $\begin{array}{l}\text { Cremon et al, } \\
2014, \text { Italy }\end{array}$ & $\begin{array}{l}\text { Outbreak of } \\
\text { GE in schools }\end{array}$ & $\begin{array}{l}\text { Self Questionnaire } \\
\text { Rome III }\end{array}$ & $\begin{array}{l}\text { Prospective } \\
\text { controlled cohort }\end{array}$ & $\begin{array}{l}75 \text { IBS of } 204 \\
\text { exposed }\end{array}$ & $\begin{array}{l}\text { Salmonella-induced gastroenteritis during } \\
\text { childhood (not adulthood) }\end{array}$ \\
\hline
\end{tabular}

IBS, irritable bowel syndrome; GE, gastroenteritis. 
matory and organic diseases, the study of early life experiences in patients with IBS has received little attention. Reported studies have been retrospective in nature, and have relied on patients' own recollection of events in order to build a better picture of the childhood risk factor. This may lead to a potential bias in recall. For example, the research on early life risk factors for IBS that were collected by Chitkara et al ${ }^{36}$ in their 2008 review had relied heavily on questionnaires that recorded participants' own recollections of childhood. Nonetheless, compared to parental and perinatal factors, the childhood risk factors of IBS have been better studied.

These risk factors span from a patient's clinical history to psycho-developmental factors and environmental factors. Regarding clinical history, antibiotic usage lasting more than 7 days, ${ }^{20}$ weight loss of more than 10 pounds, ${ }^{35}$ poor sleep ${ }^{31}$ antecedent allergic disease $^{32}$ and antecedent gastroenteritis (eg, salmonella infection) were strongly associated with an increased risk of IBS. ${ }^{34,35}$ Psychodevelopmental factors predisposing to IBS included child abuse (ie, emotional, sexual, or physical abuse) ${ }^{22,23}$ as well as psychological traits like anxiety and depression. ${ }^{16}$ Childhood environmental factors found to play an important role in the development of IBS include growing up within an affluent lifestyle, ${ }^{21}$ air pollution, ${ }^{26}$ and keeping herbivorous pets in the household. ${ }^{12}$ We think that these opposing findings may be secondary to geographical difference of the studies. A low socioeconomic status in developing countries with possible poor access to clean water or food may increase the chance of gastroenteritis and later post-infectious IBS. High socioeconomic status in developed countries bring with its own sets of issues such as academic stress.

\section{Pathophysiology: Hygiene and Gut Dysbiosis}

The hygiene and gut microbiota hypothesis postulate that early life exposure to microbial diversity regulates the composition of the gut microbiome and immunity. The gut microbiota plays an important role in IBS. The gut microbiota develops in early infancy, and the composition of gut microbiota is affected by the usage of antibiotics and gastroenteritis, which are known risk factors of IBS. Bokulich et $\mathrm{al}^{37}$ suggested that intestinal bacterial flora of infants aged 1 to 24 months are the most sensitive to disturbances from infections or antibiotic usage. During this period, even a transient and small alteration can have a lasting impact on the composition of the gut microbiome well into adulthood. Children treated with antibiotics have been shown to have intestinal microbiota with decreased stability and diversity ${ }^{38}$ and delayed maturation ${ }^{37}$ compared to $^{2}$ children not exposed to antibiotics. Hygiene factors associated with IBS include the sharing of bedrooms and exposure to pets. ${ }^{39}$ The hygiene and microflora hypothesis postulate that early life exposure to microbial diversity regulates the composition of the gut microbiome and immunity.

There are conflicting results as to the relationship between IBS and obesity. ${ }^{40,41}$ Pickett-Blakely et $\mathrm{al}^{42}$ found the prevalence of IBS in obese patients to range from $11.6 \%$ to $24.0 \%$. We do not yet understand if IBS is associated with affluence, and more studies are needed to examine the relationship between IBS and various markers of affluence such as education, obesity, and diet.

It is not known whether changes in the gut microbiota are markers or consequences of IBS. Both luminal and mucosal samples of IBS patients show reduced bacterial diversity compared to healthy individuals. Many studies have demonstrated that several microbial alterations are associated with IBS, including an increased ratio of Firmicutes/Bacteroidetes at the phylum level, increased relative abundance of fecal Ruminococcus torques-like phylotype, and reduced fecal Lactobacilli abundance. ${ }^{43,44}$ Childhood adversity and stress may predispose individuals to IBS through their effects on the gut microbiome, ${ }^{25}$ and these may mediate the pathogenesis of IBS. Taken together, IBS may be mediated by gut dysbiosis in early life.

\section{Pathophysiology: Mood and Emotional Disturbances}

Children are at increased risk of developing IBS if they were born to young mothers or if they were raised by parents with a history of IBS, mental illness, and substance abuse, anxiety, depression, and negative parenting styles. Given this finding, there may be a psychosocially-based transmission of somatic symptoms from parents to children. In a study by van Tilburg et al, ${ }^{16}$ psychological distress among children was found to correlate with the psychological distress of their mothers. In this study, children's own psychological traits, such as anxiety and depression, were associated with increased symptom reports of their parents. In Amsterdam, Zeevenhooven et $\mathrm{al}^{45}$ compared parents of 91 children with IBS or functional abdominal pain to parents of 74 healthy children. They found a difference in physical health of parents and their child-rearing styles when parents of healthy controls were compared to children with IBS. The only protective parental factors against IBS were parental emotional warmth and older maternal age. Psychosocial aspects contributing to IBS were further evaluated by Gerson et $\mathrm{al}^{46}$ in a study of 239 adult IBS patients across 8 countries. IBS symptoms were found to be directly associated with parents having relationship conflicts, but inversely associated with a deep and supportive relationship. 


\section{Intrauterine Growth Restriction and Irritable Bowel Syndrome}

Our review showed that low birth weight and intrauterine growth restriction (IUGR) might have played important roles in IBS. Low birth weight was defined as less than $2500 \mathrm{~g}$, while very low birth weight was below $1500 \mathrm{~g}$. Raslau et $\mathrm{al}^{47}$ studied the perinatal factors of IBS in a population-based nested, case-controlled study in Olmsted County. They reported that lower birth weight increased the odds of IBS. Using the birth registry of Sweden, Waehrens et al ${ }^{10}$ found that low birth weight $(<2500 \mathrm{~g})$ was a significant risk factor for IBS. Similarly, in a twin study performed by Bengtson et $\mathrm{al}^{8}$ in Sweden, low birth weight $(<1500 \mathrm{~g})$ had higher risk of IBS. In this study, the results were only significant when adjusted for gestational age, suggesting that intrauterine growth retardation (IUGR) contributed to IBS. ${ }^{8}$ IUGR describes a condition whereby a fetus cannot achieve its genetically determined potential size; a prenatal finding of restriction of growth. Genetic factors, placental factors, fetal factors, and maternal factors can all contribute to IUGR. ${ }^{48}$ It is commonly linked to preterm birth, diseases of prematurity and impairment of cognitive and motor development. ${ }^{49}$ Identification of various causes of low birth weight and IUGR may discover novel pathogenetic mechanisms involved in IBS.

\section{The Clinical Implications of the Study}

Our studies reinforce the importance of the early growing-up period in determining the risk of IBS development. In particular, the role that a warmth family plays in the protection of a child from long term suffering of IBS. More emphasis should be given to marital counseling and early recognition of psychological well-being of a child. More doctors, especially primary physicians, should be trained to pick up anxiety, depression, and sign of abuse in the very young. So that timely intervention can be executed and tackle those children in their early presentation. From the aspect of further research purposes, this study can provide a good reference for future hypothesis-driven research. As it provides evidence of the important correlation between the above-mentioned risk factors and IBS, this might encourage creating a program with a large validated database that is rigorously phenotyped; a parallel, linkable biorepository; dedicated resources for further studies. ${ }^{50}$

\section{Limitations}

Many of the included studies relied on participants' recollection of childhood experiences (eg, the onset of symptoms, parenting patterns, and history of abuse), which were subject to recall bias. Also, these studies did not use a shared, standardized definition of IBS. Compared to childhood factors, even fewer studies investigated the paternal and perinatal factors that might have influenced IBS. Our review may also suffer from selection bias, as some of the study populations included a large number of survey respondents who might have exhibited health-seeking behaviors. This review is necessarily qualitative in nature; the studies available are too heterogeneous in terms of the patient population and study design to combine for any sort of meta-analysis.

\section{Conclusion}

Our review showed that the early life period impacts the development of IBS. In fact, it strongly suggests the importance of further mechanistic studies. To improve our understanding of how each risk factor may interact and influence IBS, we will need to start at the very beginning. A life-course approach that studies both the mother and child is required to understand the link between early-life risk factors and IBS. Many common mental disorders, such as anxiety and depression, typically begin in adolescence..$^{50} \mathrm{~A}$ longitudinal study of children and adults with IBS, encompassing key time points throughout life to improve the science of IBS. ${ }^{51}$ More mechanistic studies are needed to elucidate the role of various risk factors in the pathogenesis of IBS. We also need bio-samples to provide functional data (microbiome, metabolome, and immune regulation) which will enhance the understanding on mechanisms at the molecular and microbial level, and how external factors influence pathogenesis of IBS. These will guide the development of interventions targeted at the at-risk population to alter disease trajectory. Some of these interventions include improvement of prenatal care, family counseling for supportive parent-child relationship and timely response to child symptoms and safe environment for healthy development may help to lessen the burden of IBS.

\section{Supplementary Material}

Note: To access the supplementary figure mentioned in this article, visit the online version of Journal of Neurogastroenterology and Motility at http://www.jnmjournal.org/, and at https://doi. org/10.5056/jnm20109.

\section{Financial support: None.}

Conflicts of interest: None. 
Author contributions: Kewin T H Siah contributed to the formulation of review title, formulation of questions; En X S Low contributed to the formulation of questions and coordination of the writing of the manuscript; Charles C Herndon, Evelyn X L Loo, and Elizabeth $\mathrm{H}$ Tham drafting of the manuscript and review of the manuscript; Maimouna N K Al Mandhari responsible for reviewing and writing of the manuscript; and Kewin T H Siah is also the senior author and act as guarantor.

\section{References}

1. Mearin F, Lacy BE, Chang L, et al. Bowel disorders. Gastroenterology 2016;150:1393-1407.

2. Sperber AD, Bangdiwala SI, Drossman DA, et al. Worldwide prevalence and burden of functional gastrointestinal disorders, results of rome foundation global study. Gastroenterology Online First: 12 Apr 2020. doi: 10.1053/j.gastro.2020.04.014

3. Hyams JS, Di Lorenzo C, Saps M, Shulman RJ, Staiano A, van Tilburg M. Childhood functional gastrointestinal disorders: child/adolescent. Gastroenterology 2016;150:1456-1468.e2.

4. Hulisz D. The burden of illness of irritable bowel syndrome: current challenges and hope for the future. J Manag Care Pharm 2004;10:299309.

5. Wang YT, Lim HY, Tai D, et al. The impact of irritable bowel syndrome on health-related quality of life: a Singapore perspective. BMC Gastroenterol 2012;12:104

6. Holtmann GJ, Ford AC, Talley NJ. Pathophysiology of irritable bowel syndrome. Lancet Gastroenterol Hepatol 2016;1:133-146.

7. Enck P, Aziz Q, Barbara G, et al. Irritable bowel syndrome. Nat Rev Dis Primers 2016;2:16014.

8. Bengtson MB, Rønning T, Vatn MH, Harris JR. Irritable bowel syndrome in twins: genes and environment. Gut 2006;55:1754-1759.

9. Raslau D, Herrick LM, Locke GR, et al. Irritable bowel syndrome and the perinatal period: lower birth weight increases the risk. Neurogastroenterol Motil 2016;28:1518-1524.

10. Waehrens R, Li X, Sundquist J, Sundquist K, Zöller B. Perinatal and familial risk factors for irritable bowel syndrome in a Swedish national cohort. Scand J Gastroenterol 2018;53:559-566.

11. Anand KJ, Runeson B, Jacobson B. Gastric suction at birth associated with long-term risk for functional intestinal disorders in later life. J Pediatr 2004;144:449-454.

12. Koloski NA, Jones M, Weltman M, et al. Identification of early environmental risk factors for irritable bowel syndrome and dyspepsia. Neurogastroenterol Motil 2015;27:1317-1325.

13. Levy RL, Jones KR, Whitehead WE, Feld SI, Talley NJ, Corey LA. Irritable bowel syndrome in twins: heredity and social learning both contribute to etiology. Gastroenterology 2001;121:799-804.

14. Xing Z, Hou X, Zhou K, Qin D, Pan W. The impact of parental-rearing styles on irritable bowel syndrome in adolescents: a school-based study. J Gastroenterol Hepatol 2014;29:463-468.
15. Lackner JM, Gudleski GD, Blanchard EB. Beyond abuse: the association among parenting style, abdominal pain, and somatization in IBS patients. Behav Res Ther 2004;42:41-56.

16. van Tilburg MA, Levy RL, Walker LS, et al. Psychosocial mechanisms for the transmission of somatic symptoms from parents to children. World J Gastroenterol 2015;21:5532-5541.

17. Hislop IG. Childhood deprivation: an antecedent of the irritable bowel syndrome. Med J Aust 1979;1:372-374.

18. Knight JR, Locke GR 3rd, Zinsmeister AR, Schleck CD, Talley NJ. Family history of mental illness or alcohol abuse and the irritable bowel syndrome. J Psychosom Res 2015;78:237-241.

19. Adeniyi OF, Lesi OA, Olatona FA, Esezobor CI, Ikobah JM. Irritable bowel syndrome in adolescents in Lagos. Pan Afr Med J 2017;28:93.

20. Mendall MA, Kumar D. Antibiotic use, childhood affluence and irritable bowel syndrome (IBS). Eur J Gastroenterol Hepatol 1998;10:5962.

21. Howell S, Talley NJ, Quine S, Poulton R. The irritable bowel syndrome has origins in the childhood socioeconomic environment. Am J Gastroenterol 2004;99:1572-1578.

22. Salmon P, Skaife K, Rhodes J. Abuse, dissociation, and somatization in irritable bowel syndrome: towards an explanatory model. J Behav Med 2003;26:1-18.

23. Beesley H, Rhodes J, Salmon P. Anger and childhood sexual abuse are independently associated with irritable bowel syndrome. Br J Health Psychol 2010;15(Pt 2):389-399.

24. Tietjen GE, Brandes JL, Peterlin BL, et al. Childhood maltreatment and migraine (Part III). Association with comorbid pain conditions. Headache 2010;50:42-51.

25. Dong L, Dingguo L, Xiaoxing X, Hanming L. An epidemiologic study of irritable bowel syndrome in adolescents and children in China: a school-based study. Pediatrics 2005;116:e393-e396.

26. Tan TK, Saps M, Lin CL, Wei CC. Is long-term ambient air pollutant exposure a risk factor for irritable bowel syndrome in children? A 12-year longitudinal cohort study. J Neurogastroenterol Motil 2019;25:241-249.

27. Walker EA, Katon WJ, Roy-Byrne PP, Jemelka RP, Russo J. Histories of sexual victimization in patients with irritable bowel syndrome or inflammatory bowel disease. Am J Psychiatry 1993;150:1502-1506.

28. Talley NJ, Fett SL, Zinsmeister AR, Melton LJ 3rd. Gastrointestinal tract symptoms and self-reported abuse: a population-based study. Gastroenterology 1994;107:1040-1049.

29. Talley NJ, Boyce PM, Jones M. Is the association between irritable bowel syndrome and abuse explained by neuroticism? A population based study. Gut 1998;42:47-53.

30. Son YJ, Jun EY, Park JH. Prevalence and risk factors of irritable bowel syndrome in Korean adolescent girls: a school-based study. Int J Nurs Stud 2009;46:77-85.

31. Zhou HQ, Yao M, Chen GY, Ding XD, Chen YP, Li DG. Functional gastrointestinal disorders among adolescents with poor sleep: a schoolbased study in Shanghai, China. Sleep Breath 2012;16:1211-1218.

32. Tan TK, Chen AC, Lin CL, Shen TC, Li TC, Wei CC. Preschoolers with allergic diseases have an increased risk of irritable bowel syndrome when reaching school age. J Pediatr Gastroenterol Nutr 2017;64:26-30. 
33. Rajindrajith S, Devanarayana NM, Benninga MA. Delayed or not delayed? That is the question in Indian children with constipation. Indian J Gastroenterol 2018;37:385-387.

34. Cremon C, Stanghellini V, Pallotti F, et al. Salmonella gastroenteritis during childhood is a risk factor for irritable bowel syndrome in adulthood. Gastroenterology 2014;147:69-77.

35. Thabane M, Simunovic M, Akhtar-Danesh N, et al. An outbreak of acute bacterial gastroenteritis is associated with an increased incidence of irritable bowel syndrome in children. Am J Gastroenterol 2010;105:933939.

36. Chitkara DK, van Tilburg MA, Blois-Martin N, Whitehead WE. Early life risk factors that contribute to irritable bowel syndrome in adults: a systematic review. Am J Gastroenterol 2008;103:765-774.

37. Bokulich NA, Chung J, Battaglia T, et al. Antibiotics, birth mode, and diet shape microbiome maturation during early life. Sci Transl Med 2016;8:343ra82.

38. Yassour M, Vatanen T, Siljander H, et al. Natural history of the infant gut microbiome and impact of antibiotic treatment on bacterial strain diversity and stability. Sci Transl Med 2016;8:343ra81.

39. Siah KT, Wong RK, Chan YH, Ho KY, Gwee KA. Prevalence of irritable bowel syndrome in Singapore and its association with dietary, lifestyle, and environmental factors. J Neurogastroenterol Motil 2016;22:670-676.

40. Akhondi N, Memar Montazerin S, Soltani S, et al. General and abdominal obesity in relation to the prevalence of irritable bowel syndrome. Neurogastroenterol Motil 2019;31:e13549.

41. Aasbrenn M, Høgestøl I, Eribe I, et al. Prevalence and predictors of irritable bowel syndrome in patients with morbid obesity: a cross-sectional study. BMC Obes 2017;4:22.
42. Pickett-Blakely O. Obesity and irritable bowel syndrome: a comprehensive review. Gastroenterol Hepatol (NY) 2014;10:411-416.

43. Sundin J, Öhman L, Simrén M. Understanding the gut microbiota in inflammatory and functional gastrointestinal diseases. Psychosom Med 2017;79:857-867.

44. Öhman L, Törnblom H, Simrén M. Crosstalk at the mucosal border: importance of the gut microenvironment in IBS. Nat Rev Gastroenterol Hepatol 2015;12:36-49.

45. Zeevenhooven J, Rutten JMTM, van Dijk M, Peeters B, Benninga MA. Parental factors in pediatric functional abdominal pain disorders: a cross-sectional cohort study. J Pediatr Gastroenterol Nutr 2019;68:e20e26.

46. Gerson MJ, Gerson CD, Awad RA, et al. An international study of irritable bowel syndrome: family relationships and mind-body attributions. Soc Sci Med 2006;62:2838-2847.

47. Raslau D, Herrick L, Almazar-Elder A, et al. Perinatal risk factors for the development of IBS: 1332. Am J Gastroenterol 2010;105:S492.

48. Sharma D, Shastri S, Sharma P. Intrauterine growth restriction: antenatal and postnatal aspects. Clin Med Insights Pediatr 2016;10:67-83.

49. Longo S, Bollani L, Decembrino L, Di Comite A, Angelini M, Stronati $\mathrm{M}$. Short-term and long-term sequelae in intrauterine growth retardation (IUGR). J Matern Fetal Neonatal Med 2013;26:222-225.

50. Michaud PA, Fombonne E. Common mental health problems. BMJ 2005;330:835-838.

51. Chang L, Di Lorenzo C, Farrugia G, et al. Functional bowel disorders: a roadmap to guide the next generation of research. Gastroenterology 2018;154:723-735. 